\title{
HIV-1 Tat Primes and Activates Microglial NLRP3 Inflammasome-Mediated Neuroinflammation
}

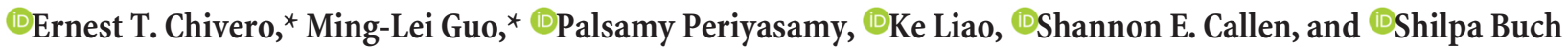 \\ Department of Pharmacology and Experimental Neuroscience, University of Nebraska Medical Center, Omaha, Nebraska 68198
}

\begin{abstract}
Neuroinflammation associated with HIV-1 infection is a problem affecting $\sim 50 \%$ of HIV-infected individuals. NLR family pyrin domain containing 3 (NLRP3) inflammasome has been implicated in HIV-induced microglial activation, but the mechanism(s) remain unclear. Because HIV-1 Transactivator of Transcription (Tat) protein continues to be present despite antiretroviral therapy and activates NF-kB, we hypothesized that Tat could prime the NLRP3 inflammasome. We found a dose- and time-dependent induction of NLRP3 expression in microglia exposed to Tat compared with control. Tat exposure also time-dependently increased the mature caspase-1 and IL-1 $\beta$ levels and enhanced the IL- $1 \beta$ secretion. These in vitro findings were validated in archival brain tissues from Simian Immunodeficiency Virus (SIV)-infected and uninfected rhesus macaques. Further validation of NLRP3 priming in vivo involved administration of lipopolysaccharide (LPS) to HIV transgenic (Tg) rats followed by assessment of IL- $1 \beta$ mRNA expression and inflammasome activation (ASC oligomers and mature IL-1 $\beta$ ). Intriguingly, LPS potentiated upregulation of IL- $1 \beta$ mRNA and inflammasome activation in HIV-Tg rats compared with the wild-type controls. Interestingly, we found an inverse relationship in the expression of NLRP3 and its negative regulator, miR-223, suggesting a miR-223-mediated mechanism for Tat-induced NLRP3 priming. Furthermore, blockade of NLRP3 resulted in decreased IL-1 $\beta$ secretion. Collectively, these findings suggest a novel role of Tat in priming and activating the NLRP3 inflammasome. Therefore, NLRP3 can be envisioned as a therapeutic target for ameliorating Tat-mediated neuroinflammation.
\end{abstract}

Key words: HIV-1 Tat; inflammasome; microglia; neuroinflammation; NLRP3

\section{Significance Statement}

Despite successful suppression of viremia with increased longevity in the era of combined antiretroviral therapy, chronic inflammation with underlying neurocognitive impairment continues to afflict almost $50 \%$ of infected individuals. Viral, bacterial, and cellular products have all been implicated in promoting the chronic inflammation found in these individuals. Understanding the molecular mechanism(s) by which viral proteins such as HIV-1 Transactivator of Transcription (Tat) protein can activate microglia is thus of paramount importance. Herein, we demonstrate a novel role of Tat in priming and activating NLR family pyrin domain containing 3 (NLRP3) inflammasomes in microglial cells and in HIV-Tg rats administered lipopolysaccharide. Targeting NLRP3 inflammasome pathway mediators could thus be developed as therapeutic interventions to alleviate or prevent neuroinflammation and subsequent cognitive impairment in HIV-positive patients.

\section{Introduction}

HIV-1-associated neurocognitive disorders (HAND) collectively describes a spectrum of neurocognitive impairments that in-

\footnotetext{
Received Sept. 29, 2016; revised Jan. 30, 2017; accepted Feb. 24, 2017.

Author contributions: E.T.C., M.-L.G., P.P., S.E.C., and S.B. designed research; E.T.C., M.-L.G., P.P., K.L., and S.E.C. performed research; E.T.C.,M.-L.G., P.P.,S.E.C., and S.B. analyzed data; E.T.C.,M.-L.G.,P.P., S.E.C., and S.B. wrote the paper.

This work was supported by the National Institutes of Health (Grants R01DA036157, R01DA035203, R01DA033150, and R01DA040397 to S.B.). E.T.C. was supported by the International AIDS Society (IAS), the National Institute on Drug Abuse (NIDA), and French National Agency for Research on AIDS and Viral Hepatitis (Agence Nationale de Recherche) as a recipient of the HIV and drug use research fellowship. We thank Guoku Hu, Eric Tom, Annadurai Thangaraj, and Susmita Sil for useful discussion and Yeon Hee Kook and Fang Niu for technical assistance. The authors declare no competing financial interests.

*E.T.C. and M.-L.G. contributed equally to this work.

Correspondence should be addressed to Shilpa Buch, Department of Pharmacology and Experimental Neuroscience, University of Nebraska Medical Center, 985880 Nebraska Medical Center (Room 8011), Omaha, NE 68198. E-mail: sbuch@unmc.edu.
}

cludes asymptomatic neurocognitive impairment (ANI), mild neurocognitive disorder (MND), and HIV-1-associated dementia (HAD) that is associated with functional alterations in neurons (Antinori et al., 2007; Saylor et al., 2016). HAND develops in an estimated $20-50 \%$ of HIV-1-infected people despite the increased availability of effective combined antiretroviral therapy (cART) regimens (Maschke et al., 2000; Sacktor et al., 2002; Gray et al., 2003; McArthur et al., 2003; Heaton et al., 2011; Nightingale et al., 2014; Saylor et al., 2016). In cART-treated individuals, HAND commonly manifests as deficits in executive function, learning, and memory, thus significantly reducing the quality of life (Saylor et al., 2016). Although the mechanism(s) leading to HAND is not clearly understood, it is associated with heightened 
levels of cellular and oxidative stress, disturbances in energy metabolism, glutamate regulation, immune activation, inflammation, and neuronal injury (Saylor et al., 2016). Intriguingly, it is not clearly understood why CNS inflammation remains elevated despite suppression of viral replication by cART. In the current study, we hypothesize that the HIV-1 Tat protein primes microglial inflammation mediated by NLR family pyrin domain containing 3 (NLRP3) inflammasomes.

Previous reports have demonstrated HIV-1-mediated triggering of the NLRP3 inflammasome in the CNS and subsequent release of the proinflammatory cytokines IL-1 $\beta$ and IL-18 (Walsh et al., 2014). Furthermore, it has been well documented that IL- $1 \beta$ is increased in the CNS during lentiviral infection (Zhao et al., 2001; Xing et al., 2009; Maingat et al., 2013) and is released into the supernatants of glial cultures in response to HIV-1 infection or after exposure to HIV-1 glycoproteins (Merrill et al., 1992; Koka et al., 1995; Walsh et al., 2014). Therefore, whereas the capacity of HIV-1 infection to induce NLRP3 inflammasome activation has been well described, the precise molecular mechanism(s) underlying HIV-1mediated NLRP3 activation remains poorly understood. Apart from its role as a transcriptional signal, HIV-1 Tat has been widely suggested to underlie the ongoing inflammation associated with HIV-1 (Nath et al., 1999; Weiss et al., 1999; Gannon et al., 2011; Zayyad and Spudich, 2015). Moreover, exposure of monocytes to Tat has been reported to stimulate IL- $1 \beta$ release (Nath et al., 1999; Yang et al., 2010). Furthermore, despite cART, there is the presence of Tat and other viral proteins in the brain and peripheral organs of HIV-1-infected people, thereby contributing to the smoldering low-level inflammation often associated with HAND. Because the main target cells for HIV-1 infection in the CNS are myeloid cells such as microglia, which can both release and uptake soluble Tat, we focused on the role of Tat in activating the NLRP3 inflammasome in microglial cells.

NLRP3 inflammasome creation is a two-step process involving signals 1 and 2; signal 1 is for priming or preparing the pathway by enhancing levels of NLRP3 and pro-IL- $1 \beta$ and signal 2 is for triggering the processing of caspase- 1 and subsequent maturation and release of IL-1 $\beta$ (Gross et al., 2011; Rathinam et al., 2012; Sutterwala et al., 2014; Moon et al., 2015). Because Tat is known to activate NF-kB (signal 1) (Demarchi et al., 1996; Dandekar et al., 2004; Fiume et al., 2012), we hypothesized that Tat could thus prime the NLRP3 inflammasome. In this study, we report Tat-mediated NLRP3 upregulation, subsequent maturation of caspase- 1 , and discharge of IL- $1 \beta$ from microglia. We also demonstrate that pharmacological inhibition (by glyburide) and genetic silencing (NLRP3 siRNA) of NLRP3 attenuated caspase-1 processing and IL-1 $\beta$ release. Furthermore, we confirmed these in vitro findings in brain samples isolated from Simian Immu- nodeficiency Virus (SIV)-positive monkeys. Herein, we demonstrate a novel role of Tat in activating the NLRP3 inflammasome in microglial cells and further demonstrate that the therapeutic potential of NLRP3 inhibition could be useful in attenuating or preventing the development of HAND in HIV-1-infected individuals.

\section{Materials and Methods}

Reagents. The following antibodies or reagents used in this study were from the indicated sources: NLRP3 (AdipoGen catalog \#AG-20B-0014 RRID:AB_2490202); ASC (apoptosis-associated speck-like protein containing a CARD) (Santa Cruz Biotechnology catalog \#sc-22514-R RRID: AB_2174874), caspase-1 (Santa Cruz Biotechnology catalog \#sc-514 RRID: AB_2068895), goat anti-mouse-HRP (Santa Cruz Biotechnology catalog \#sc-2005 RRID:AB_631736) and goat anti-rabbit-HRP (Santa Cruz Biotechnology catalog \#sc-2004 RRID:AB_631746); IL-1 $\beta$ (Abcam catalog \#ab9722 RRID:AB_308765); actin (Sigma-Aldrich catalog \#A1978 RRID:AB_476692). Cryopyrin/NLRP3 siRNA (sc-45470) was from Santa Cruz Biotechnology. Glyburide (SYN-3026-M050) was from Adipogen. TaqMan microRNA assays for miR-223 (PN4427975) quantification were from Applied Biosystems. Endotoxin-free HIV-1 TAT-101 was from Immunodiagnostics.

Animals. All animal procedures were performed in strict accordance with the protocols approved by the Institutional Animal Care and Use Committee of the University of Nebraska Medical Centre and the National Institutes of Health. Sprague Dawley rats and C57BL/6N mice 
A
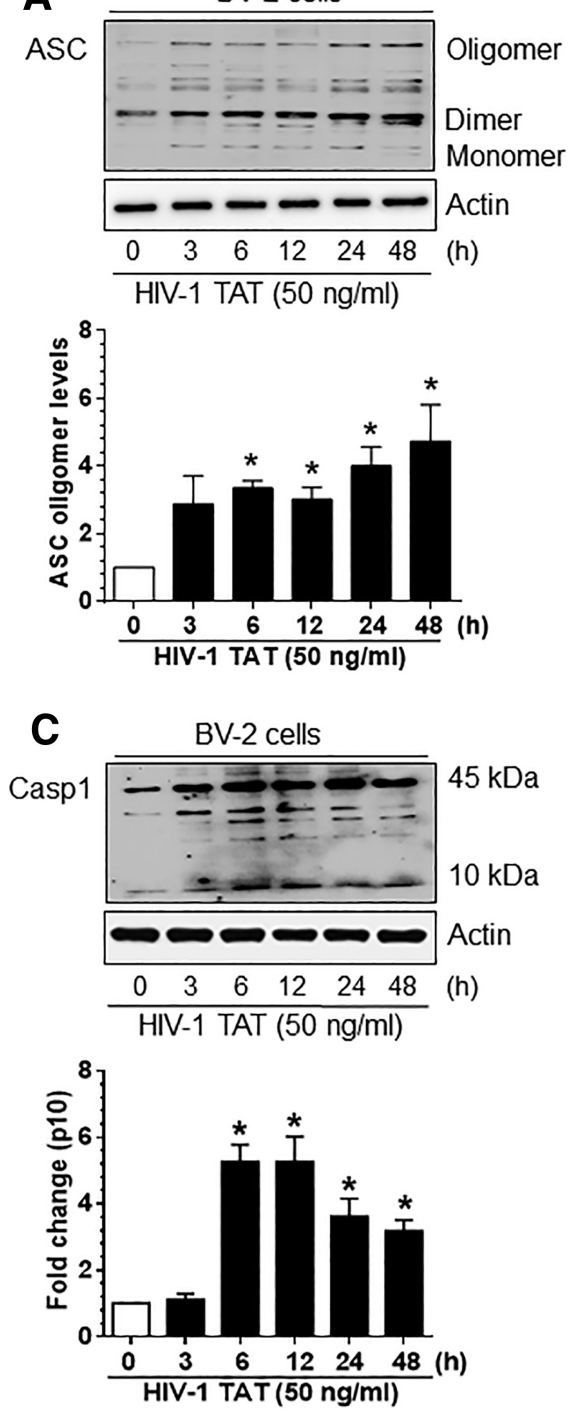

B
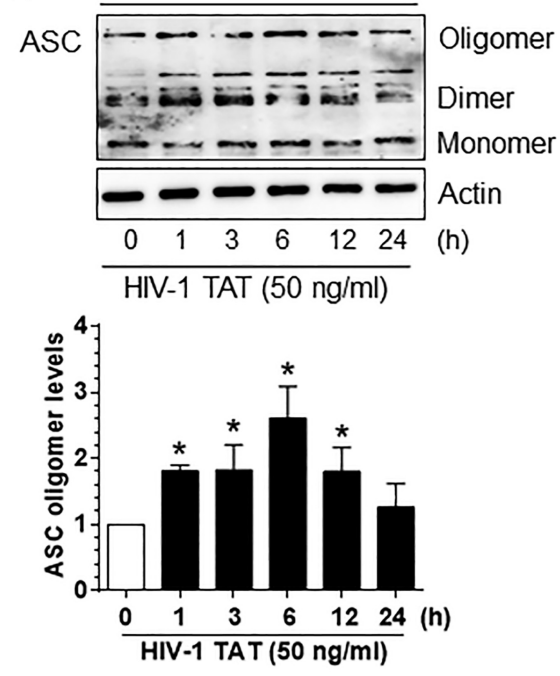

D
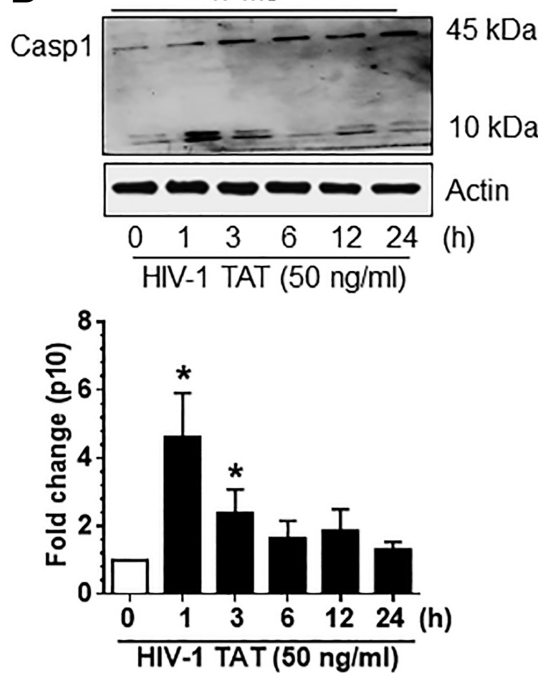

Figure 2. HIV-1 Tat-induced ASC oligomerization and pro-caspase-1 cleavage in BV-2 and rPMs. Cells were seeded in six-well plates and exposed to Tat $(50 \mathrm{ng} / \mathrm{ml})$ for the indicated time periods. Tat induced ASC multimerization in a time- dependent manner in both BV-2 and rPMs $(\boldsymbol{A}, \boldsymbol{B})$. Cleaved caspase-1 (p10) rapidly increased ( $\sim 4$-fold) and gradually declined in both BV-2 and rPMs $(\boldsymbol{C}, \boldsymbol{D})$. All experiments were performed at least three independent times and representative figures are shown. Actin served as a loading control. Quantification of Western blots is shown under each blot. Data are shown as mean \pm SEM.

were purchased from Charles River Laboratories and housed under conditions of constant temperature and humidity on a $12 \mathrm{~h}$ light, $12 \mathrm{~h}$ dark cycle, with lights on at $0700 \mathrm{~h}$. Food and water were available ad libitum. Archival plasma and brain tissues from SIV-infected rhesus macaques were used in this study. These groups included monkeys that were uninfected, acute infected ( 3 weeks), and chronically infected ( $\sim 52$ weeks) with SIVR71/17E. Details of virus load and disease pathogenesis have been described previously (Bokhari et al., 2011; Hu et al., 2012).

In vivo lipopolysaccharide (LPS) administration. In-house-bred HIV-1 $\mathrm{Tg}$ rats of mixed gender expressing a noninfectious HIV-1 provirus transgene with a deletion of gag and pol genes (Reid et al., 2001) were administrated either LPS (0127:B8, Sigma-Aldrich, $1 \mathrm{mg} / \mathrm{kg}$, i.p.) or saline ( $n=4$ per group). Either age-matched wild-type non-Tg rats administrated LPS or saline were used as controls. Rats were killed by isoflurane anesthesia $3 \mathrm{~h}$ after LPS injection for brain removal. The striatal region of the brain was separated and used for extraction of total RNA and protein. mRNA and protein levels of proinflammatory cytokines were assessed by qRT-PCR and Western blotting, respectively. To assess the activation status of NLRP3 inflammasome pathway, levels of ASC oligomerization and mature IL- $1 \beta$ were detected by Western blotting.
Isolation of primary rat primary microglia ( $r P M s)$.rPMs were isolated from the brains of newborn Sprague Dawley pups as described previously (Guo et al., 2015; Liao et al., 2016). Briefly, brain cortices were dissociated and digested in Hank's buffered salt solution (Invitrogen, catalog \#14025076) supplemented with $0.25 \%$ trypsin (Invitrogen, catalog \#25300-054). Mixed glial cultures were prepared by resuspending cells in culture DMEM supplemented with $10 \%$ heat-inactivated FBS with $100 \mathrm{U} / \mathrm{ml}$ penicillin and $0.1 \mathrm{mg} / \mathrm{ml}$ streptomycin, as described previously (Guo et al., 2015). Cells were transferred to T-75 cell culture flasks $\left(10 \times 10^{6}\right.$ cells/flask $)$, incubated at $37^{\circ} \mathrm{C}$ and $5 \% \mathrm{CO}_{2}$, and half of the cell medium was replaced every $3-5 \mathrm{~d}$. At the first medium change, macrophage colony-stimulating factor (Invitrogen, catalog \#PHC9504) was added (0.25 ng/ $\mathrm{ml}$ ) to promote microglial proliferation. Confluent mixed glial cultures ( 7 to $10 \mathrm{~d}$ ) were shaken at $37^{\circ} \mathrm{C}, 220 \times g$ for $2 \mathrm{~h}$ to promote microglia detachment. Cell medium containing released microglia cells was aspirated, centrifuged at $1000 \times g$ for $5 \mathrm{~min}$, and microglia plated on cell culture plates for all ensuing experiments. Immunohistochemical staining with antibodies specific for IBA1 was used to evaluate the purity of the isolated microglial cultures and was routinely found to be $>95 \%$ pure.

$B V-2$ cell culture. The BV-2 microglial cell line was generously provided by Dr. Sanjay Maggirwar (University of Rochester Medical Center, Rochester, NY). Cells were grown and routinely maintained at $37^{\circ} \mathrm{C}$ and $5 \% \mathrm{CO}_{2}$ in DMEM supplemented with $10 \%$ heat-inactivated FCS, $100 \mathrm{IU} / \mathrm{ml}$ penicillin, and $100 \mu \mathrm{g} / \mathrm{ml}$ streptomycin.

Western blotting. Treated cells were lysed with RIPA buffer supplemented with protease inhibitor mixture (Thermo Fisher Scientific, catalog \#78430), followed by ultrasonication for $3 \mathrm{~s}$ at $80 \%$ amplitude and Western blotting performed as described previously (Guo et al., 2015; Liao et al., 2016). Briefly, lysates were cleared by centrifugation at $12000 \times g$ for 10 $\min$ at $4^{\circ} \mathrm{C}$. Protein concentration was quantified by BCA method (Thermo Fisher Scientific, catalog \#23225). Equal amounts of protein $(10-20 \mu \mathrm{g})$ were electrophoresed in a SDSpolyacrylamide gel under reducing conditions. After transfer, PVDF membranes (Millipore, catalog \#IPVH00010) were blocked with 5\% nonfat dry milk for at least $60 \mathrm{~min}$ at room temperature. Membranes were then probed with primary antibodies overnight at $4^{\circ} \mathrm{C}$, washed with TBS-T, incubated with appropriate HRP-conjugated secondary antibodies, and developed with SuperSignal West Dura or Femto substrate. Densitometric analyses were performed using ImageJ version 1.44 software. Protein amounts for bands of interest were normalized to $\beta$-actin.

ASC complex isolation. Freshly prepared disuccinimydyl suberate ( $5 \mathrm{~mm}$; Thermo Fisher Scientific, catalog \#21555) was added to protein lysates isolated from animals treated with LPS or saline and incubated at room temperature for $30 \mathrm{~min}$. Samples were centrifuged at $300 \times g$ for 10 $\min$ at $4^{\circ} \mathrm{C}$. Supernatants were removed and the cross-linked pellets were resuspended in Laemmli sample buffer, boiled for $7 \mathrm{~min}$ at $99^{\circ} \mathrm{C}$, and analyzed by Western blotting.

Small interfering RNA (siRNA) transfection. siRNA transfections were performed using Lipofectamine 2000 (Life Technologies, catalog 11668027) according to the manufacturer's instructions. Briefly, cells were transfected with targeted siRNA or scrambled siRNA (20 pM) mixed with $6 \mu$ l 
of Lipofectamine 2000 diluted in $150 \mu \mathrm{l}$ of optiMEM (Life Technologies, catalog \#31985062). The resulting siRNA-lipid complexes were added onto cells, incubated for $6 \mathrm{~h}$, and the medium changed into fresh DMEM. Cells were then treated with $50 \mathrm{ng} / \mathrm{ml}$ TAT or control and harvested at $24 \mathrm{~h}$ after transfection as described previously (Guo et al., 2015; Liao et al., 2016). Knock-down efficiencies were determined by Western blotting.

qRT-PCR. qRT-PCR was performed as described previously (Guo et al., 2015; Liao et al., 2016). Briefly, total RNA was extracted using TRIzol reagent (Invitrogen, catalog \#15596018) according to the manufacturer's instructions and RNA yield quantified by NanoDrop 2000 (Thermo Fisher Scientific). RNA was transcribed into complementary DNA using Verso cDNA kit (Invitrogen, catalog \#AB-1453/B) according to the manufacturer's instructions. qRTPCR was performed with SYBR Green ROX qPCR Mastermix (Qiagen, catalog \#330510). Reaction systems were set up as follows: $10 \mu$ of SYBR Green Mastermix, $0.5 \mu \mathrm{l}$ of forward primers, $0.5 \mu \mathrm{l}$ of reverse primers, $7 \mu \mathrm{l}$ of distilled water, and $2 \mu \mathrm{l}$ of cDNA. Then, 96-well plates were placed into a 7500 Fast real-time PCR system (Applied Biosystems) for program running. Mouse primers for NLRP3 ID \#22003870a1) and IL- $1 \beta$ (ID \#6680415a1) from the PrimerBank (Wang et al., 2012) were from Invitrogen. Rat primers for IL- $1 \beta$ (forward: GCACA GTTCCCCAACTGGTA and reverse: ACAC GGGTTCCATGGTGAAG), IL-6 (forward: GGACCAAGACCATCCAACTCA and reverse: CCACAGTGAGGAATGTCCACA) and GAPDH (forward: TGCACCACCAACTGCTTAGC and reverse: ATGCCAGTGAGCTTCCCGTT) were used.

miR-223 qRT-PCR. TaqMan microRNA assays for miR-223 were commercially available from Applied Biosystems. The TaqMan MicroRNA Reverse Transcription Kit (PN 4366596) was used according to indicated protocol. The reaction system $(15 \mu \mathrm{l})$ was set as followed: $10 \mathrm{~mm}$ dNTPs (with dTTP) $1.5 \mu \mathrm{l}$, MultiScribe Reverse Transcriptase $50 \mathrm{U} / \mu \mathrm{l} 1.0 \mu \mathrm{l}, 10 \times$ reverse transcription buffer $1.5 \mu \mathrm{l}$, RNase inhibitor, $20 \mathrm{U} / \mu \mathrm{l} 0.2 \mu \mathrm{l}$, nuclease-free water to $7 \mu \mathrm{l}$, total RNA $5 \mu \mathrm{l}(\sim 50 \mathrm{ng}), 3 \mu \mathrm{l}$ of reverse transcription $(\mathrm{RT})$ primer $(5 \times)$. Thermal cycler conditions for RT were as follows: $16^{\circ} \mathrm{C}$ for $30 \mathrm{~min}, 42^{\circ} \mathrm{C}$ for $30 \mathrm{~min}, 85^{\circ} \mathrm{C}$ for $5 \mathrm{~min}$. The RT product was then diluted 1:10 for the following PCR: TaqMan PCR primer $(20 \times) 1 \mu \mathrm{l}$, RT reaction product $1.5 \mu \mathrm{l}$, TaqMan $2 \times$ Universal PCR Master Mix, No AmpErase UNGa $10 \mu \mathrm{l}$ (PN 4324018), and distilled water up to $20 \mu$ l. The PCR conditions were as follows: hold $95^{\circ} \mathrm{C}$ for 10 min, 40 cycles for $95^{\circ} \mathrm{C}$ for $15 \mathrm{~s}$, and $60^{\circ} \mathrm{C}$ for $1 \mathrm{~min}$. All reactions were run in triplicate. The expression level of miR-223 was calculated by normalizing to U6 snRNA.

Cytokine assay. Serum IL-1 $\beta$ and IL-18 were quantified by multiplex assay on an MAGPIX Luminex instrument according to manufacturer's instructions. For ELISA assays, microglial cells (8000 cells/well) were seeded into 96-well plates overnight and medium replaced with medium containing Tat or controls. Supernatants were collected at $24 \mathrm{~h}$ after Tat treatment and IL- $1 \beta$ production was quantified by ELISA using a mouse IL- $1 \beta$ ELISA kit (DY401; R\&D Systems) according to the manufacturer's instructions. Six wells per each dose treatment were analyzed.

Statistical analysis. Graphs and statistical analyses were performed using GraphPad Prism software version 5.0. Student's $t$ test was used to compare results between test and controls. One-way ANOVA was used for multiple comparisons. $p<0.05$ was considered statistically significant. six replicates per condition.
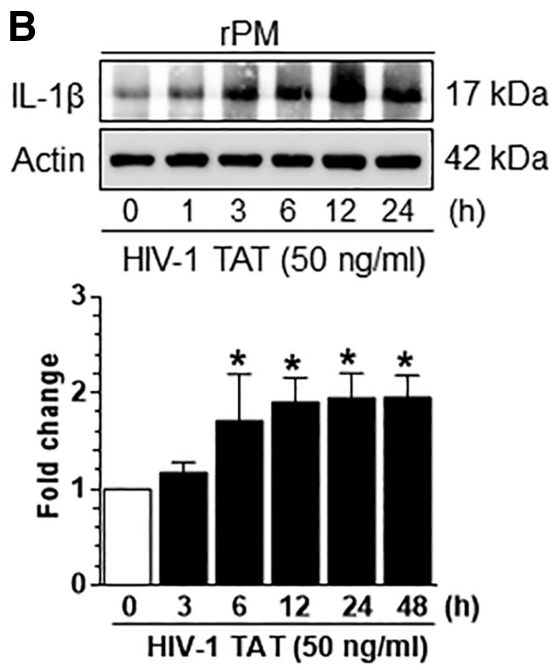

D

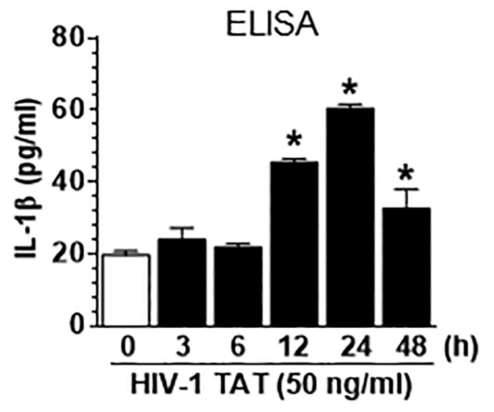

Figure 3. HIV-1 Tat-induced IL-1 $\beta$ cleavage and release in microglia. Microglial cells were seeded into six- or 96 -well plates for Western blotting (WB) or ELISA, respectively. Exposure to Tat $(50 \mathrm{ng} / \mathrm{ml})$ induced cleavage of IL-1 $\beta$, resulting in the detection of Western blots is shown under each blot. Data are shown as mean + SEM. IL-1 $\beta$ was released into supernatants in a timedependent manner in both BV-2 cells $(\boldsymbol{C})$ and primary microglia $(\boldsymbol{D})$ as quantified by ELISA. ELISA experiments were performed with

\section{Results}

Tat primes microglial NLRP3 inflammasome by upregulating NLRP3 expression

Tat has been well characterized to activate myeloid cells resulting in the release of a plethora of proinflammatory factors including IL- $1 \beta$. However, the detailed mechanism(s) underlying Tat effects remains unexplored. In this current study, we investigated whether exposure of microglial cells to Tat sets up or primes the NLRP3 inflammasome by increasing NLRP3 expression in these cells. BV-2 and rPMs were exposed to Tat $(0,12.5,25,50$, and 100 $\mathrm{ng} / \mathrm{ml}$ ) and evaluated for NLRP3 expression. As shown in Figure $1, A$ and $B$, Tat-induced NLRP3 protein expression in a dosedependent manner, with significant increases observed at 50 $\mathrm{ng} / \mathrm{ml}$ Tat in both BV-2 cells and rPMs. As anticipated, LPS (50 $\mathrm{ng} / \mathrm{ml}$ ), an eminent inflammasome priming agent, led to a significant increase in NLRP3 expression with a $>3$-fold increase (Fig. 1A). To explore whether NLRP3 mRNA levels were also elevated by Tat exposure, we also analyzed NLRP3 mRNA expression levels in BV-2 cells and found a dose-dependent increase in NLRP3 mRNA (data not shown). Based on these findings, the lowest dose of Tat $(50 \mathrm{ng} / \mathrm{ml})$ that upregulated expression of NLRP3 was thus chosen for all the ensuing experiments.

The next step was to examine the time course of Tat-mediated expression of NLRP3 protein. As shown in Figure 1C, we ob- 
A
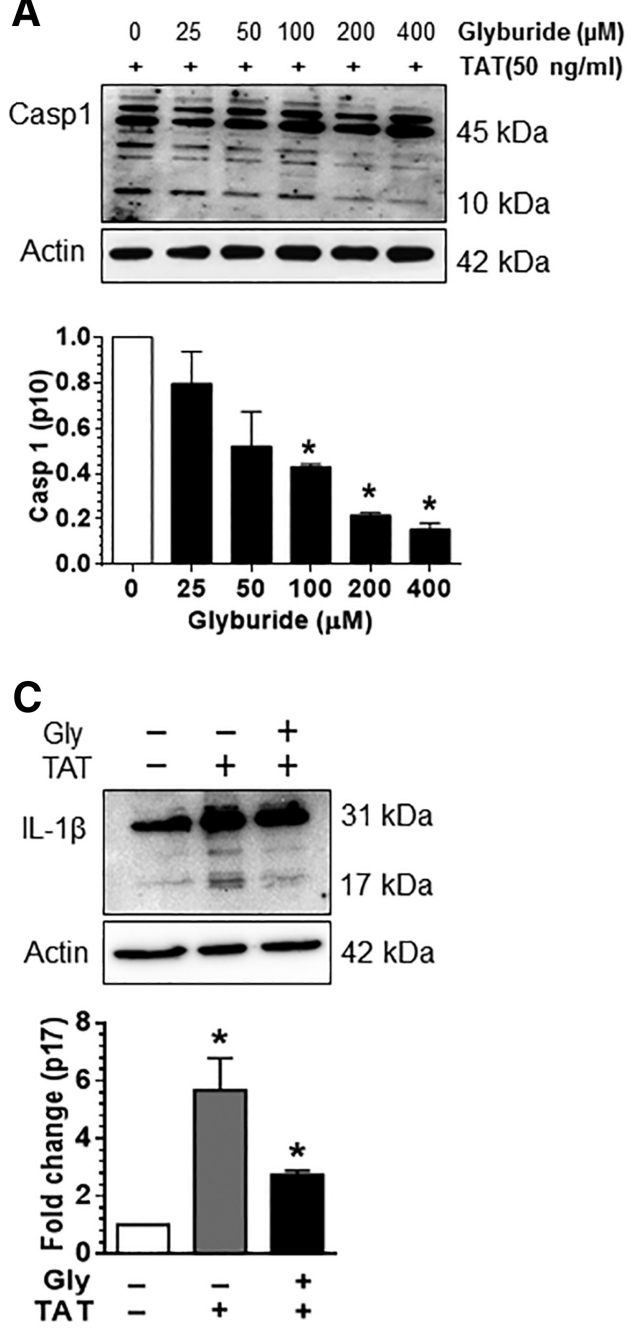

B
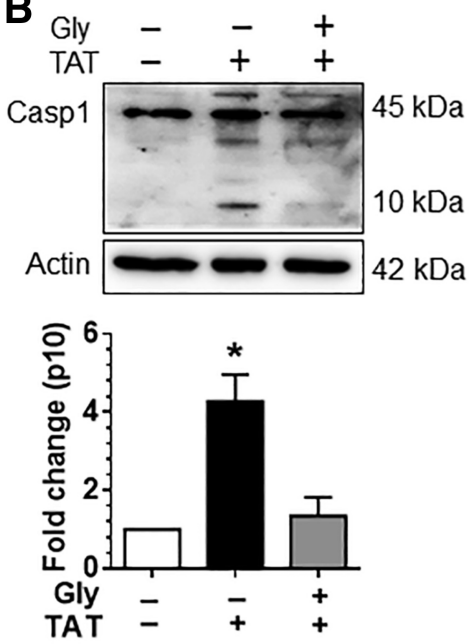

D

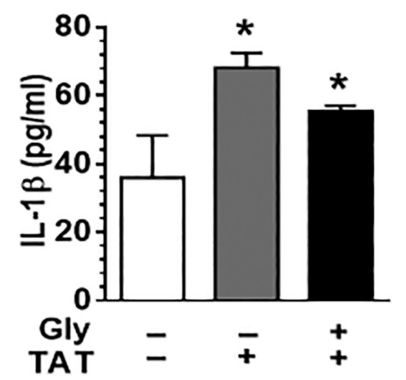

Tat exposure resulted in a sustained increase in the expression of ASC oligomers in BV-2 cells up to the longest time point assayed (48 h). In rPMs, Tat exposure resulted in a significant increase in ASC oligomers at $6 \mathrm{~h}$, followed by a gradual decline (Fig. 2B). These data demonstrate that Tat could induce ASC oligomerization in a time-dependent manner, suggesting that Tat mediates nucleation and formation of NLRP3-ASC inflammasome complexes in microglia.

Next, we examined the time course of Tat-mediated caspase- 1 cleavage. As shown in Figure 2, $C$ and $D$, Tat exposure resulted in the rapid cleavage of pro-caspase- 1 into its mature form (p10) within the first $6 \mathrm{~h}$, reaching an $\sim 5$-fold increase and gradually declining. Together, these data suggest that Tat can induce ASC oligomerization and caspase-1 cleavage in microglia.

Tat-mediated processing and release of IL-1 $\beta$ in microglial cells

Having demonstrated NLRP3 priming and formation of inflammasome as evidenced by ASC oligomerization and caspase- 1 cleavage, we next sought to confirm the complete activation of NLRP3 by assessing the processing of the end product, IL$1 \beta$, with its subsequent release into the culture supernatant. As revealed in Figure $3, A$ and $B$, Tat exposure led to a timedependent intracellular increase $(\sim 2$ fold) in the mature form of IL- $1 \beta$ (p17) from $6-48 \mathrm{~h}$, suggesting that Tat activated the processing of IL- $1 \beta$ into its mature form in both BV-2 cells and rPMs. Next, we assayed Tat-mediated release of $\mathrm{IL}-1 \beta$ in the culture medium and observed a significant time-dependent increase in IL- $1 \beta$ release in both BV-2 cells

served significantly increased expression of NLRP3 protein at $6 \mathrm{~h}$ after Tat exposure $(50 \mathrm{ng} / \mathrm{ml})$, with a sustained increase up to $48 \mathrm{~h}$ $(p<0.05)$ in BV-2 cells. These findings were also validated in rPMs exposed to Tat and revealed a gradual increase in NLRP3, with a 6 -fold peak at $12 \mathrm{~h}$ after Tat exposure, followed by a reduction at $24 \mathrm{~h}$ (Fig. 1D). Expectedly, heated Tat had no effect on NLRP3 expression, suggesting a requirement for native conformation of Tat for NLRP3 upregulation (data not shown). Collectively, these data imply that Tat can set up or prime the NLRP3 inflammasome by enhancing NLRP3 and IL-1 $\beta$ expression in microglia.

Time-dependent effects of Tat on ASC oligomerization and caspase-1 cleavage in microglial cells

After NLRP3 priming, the inflammasome is formed by the recruitment of both ASC and pro-caspase-1 protein. Because ASC functions as a molecular platform for protein-protein interactions through the formation of oligomers manifesting as large disc-like structures (de Alba, 2009; Rathinam et al., 2012), we next wanted to verify the formation of these ASC oligomers in microglial cells exposed to Tat $(50 \mathrm{ng} / \mathrm{ml})$. As shown in Figure $2 A$, and rodent primary microglia $(p<0.001$; Fig. $3 C, D)$. At least 30 $\mathrm{pg} / \mathrm{ml} \mathrm{IL}-1 \beta$ was released into the culture medium at $12 \mathrm{~h}$ after Tat exposure. Intriguingly, these data underscore the role of Tat as an NLRP3 inflammasome activation signal.

\section{Pharmacological and genetic silencing of NLRP3 attenuates} caspase- 1 processing and IL-1 $\beta$ release

Having demonstrated that Tat activated the microglial NLRP3 inflammasome, we then investigated whether inhibition of NLRP3 would diminish Tat-mediated microglial inflammatory response. To address this, Tat-primed BV-2 cells were exposed to glyburide, an NLRP3 inhibitor (Lamkanfi et al., 2009), and analyzed for cleaved caspase-1 (p10) and release of IL- $1 \beta$. As presented in Figure $4 A$, we observed a dose-dependent inhibition of caspase- 1 processing into its mature cleaved products. In the presence of $200 \mu \mathrm{M}$ glyburide, there was inhibition of Tatmediated caspase-1 processing, resulting in reduced expression of p10 compared with cells exposed to Tat only (Fig. $4 B$ ). Similarly, and as shown in Figure 4C, mature IL-1 $\beta$ (p17) was attenuated in Tat-primed cells subsequently treated with glyburide. To confirm its release, we next quantified IL- $1 \beta$ in culture 
medium obtained from these Tatprimed, glyburide-treated cells using ELISA. As shown in Figure $4 D$, we observed significantly reduced IL- $1 \beta$ released into the culture supernatants of Tatprimed, glyburide-treated cells compared with controls $(p<0.05)$, suggesting that pharmacological inhibition of NLRP3 attenuated Tat-induced NLRP3 inflammasome activation.

The next step was to use a genetic approach to validate the results obtained by the pharmacological approach. To this end, BV-2 cells were transfected with NLRP3 siRNA or scrambled siRNA, followed by exposure to Tat for $24 \mathrm{~h}$. As shown in Figure $5 A$, transfection of cells with NLPR3 siRNA resulted in downregulation of NLRP3 expression (Fig. 5A, lane 1 vs lane 3$)$. As expected, Tat-primed cells transfected with NLRP3 siRNA failed to upregulate NLRP3 compared with control cells (Fig. 5A, lane 2 vs lane 4). In NLRP3 knock-down cells, Tat priming tended to reduce the formation of ASC oligomerization (Fig. 5B), underpinning the role of NLRP3 in Tat-mediated priming and activation of the NLRP3 inflammasome. Caspase-1 processing was also attenuated, resulting in lower expression of p10 compared with scrambled siRNA transfected cells (Fig. 5C). Similarly, and as shown in Figure $5 D$, the mature IL- $1 \beta$ (p17) was reduced in Tat-primed, NLRP3 siRNA-transfected cells. In summary, we provide evidence that underscores the role of NLRP3 in Tat-mediated microglial activation.

Tat modulates NLRP3 inflammasome activation by inhibiting the expression of its negative regulator, $\mathrm{miR}-223$ Having established that Tat primes and activates the NLRP3 inflammasome, we sought to investigate the mechanism by which Tat upregulated NLRP3 levels. miRNAs are small, noncoding RNA molecules of $\sim 21-25$ nt well known to regulate gene expression (Ambros, 2004; Filipowicz et al., 2008). Previous reports showed that miR-223 inhibits NLRP3 protein levels by binding to the $3^{\prime}$-untranslated region $\left(3^{\prime}\right.$-UTR) of NLRP3 mRNA and targeting it for degradation (Bauernfeind et al., 2012; Haneklaus et al., 2012). Whether miR-223 is involved in Tat-mediated NLRP3 upregulation has not been explored to date. To test this hypothesis, microglia were exposed to Tat and monitored for the expression of miR-223 and NLRP3 mRNA levels over a $24 \mathrm{~h}$ time course. Microglia are enriched for and express high constitutive levels of miR-223 (Jovičić et al., 2013). As shown in Figure 6, $A$ and $B$, after Tat exposure, miR-223 expression was time-dependently downregulated in both BV-2 and mouse primary microglia. Correspondingly, we also sought to assess levels of NLRP3 mRNA in microglial cells exposed to Tat for varying times. After Tat exposure, there was an enhanced expression of NLRP3 mRNA ( $\sim 2$-fold) at $6 \mathrm{~h}$ after treatment in both BV-2 and primary rodent cells (Fig. $6 C, D ; p<0.05$ ). Our and IL-1 $\beta$ p 17 (D).
B
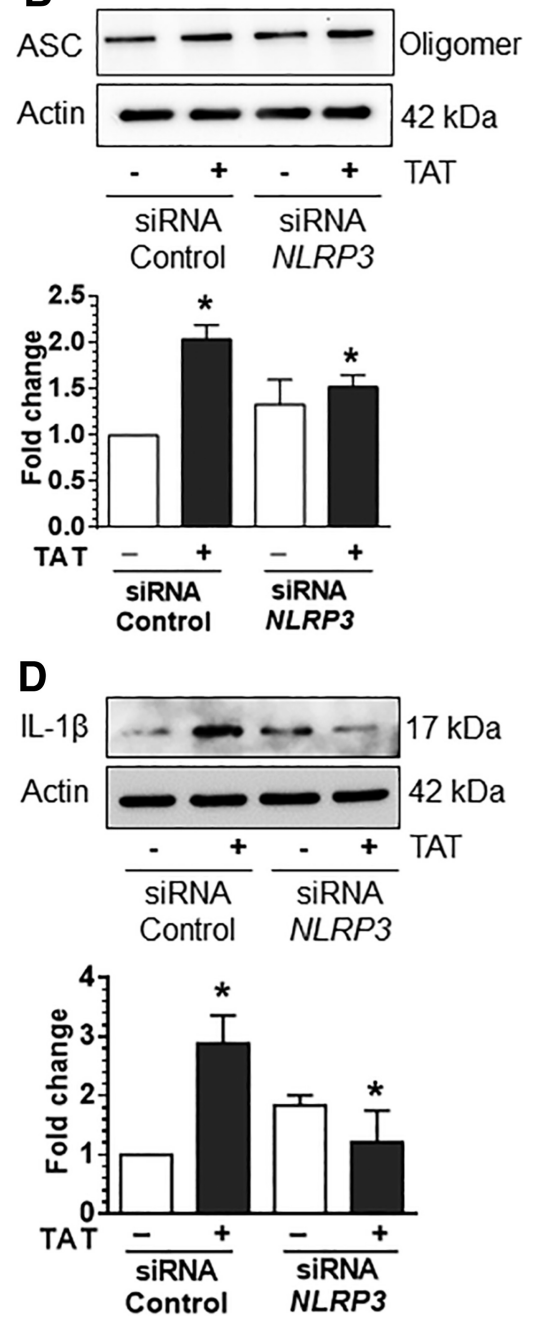

Figure 5. Knock-down of NLRP3 by siRNA attenuated inflammasome pathway in microglia. BV-2 cells were seeded into six-well siNLRP3 knock-down ( $\boldsymbol{A}$; lane 1 vs lane 3 ). Tat priming failed to increase NLRP3 levels compared with siRNA-treated control cells $(\boldsymbol{A}$, lane 2 vs lane 4). Tat priming of siNLRP3 knock-down cells resulted in reduced formation of ASC dimers (B), caspase-1 p10 (C),

results reveal an inverse relationship between expression of miR223 and its $3^{\prime}$-UTR target, NLRP3. In addition, we assessed the time course expression of $I L-1 \beta$ mRNA levels and confirmed concurrent Tat-mediated priming with NLRP3, as shown in Figure $6, E$ and $F$. These findings such suggest that Tat-mediated downregulation of miR-223 plays a role in upregulating its target, NLRP3, leading to increased priming.

Increased expression of NLRP3 pathway mediators in the brains of SIV-infected macaques

Having ascertained the role of Tat in NLRP3 inflammasome priming and activation in vitro, we next sought to confirm whether markers of the NLRP3 inflammasome pathway were also upregulated in SIV-infected monkeys in vivo. Monkeys $(n=$ 3 /group) were infected with SIVmacR71/17E and monitored at 2 weeks after infection (acute) and at necropsy (maximum 52 weeks) for ASC, IL-1 $\beta$, and IL-18 levels in the brain and in the plasma. Viral loads and animal characteristics are given in Table 1. We observed significantly enhanced IL- $1 \beta$ levels in the basal ganglia of both acute and chronically infected animals compared 

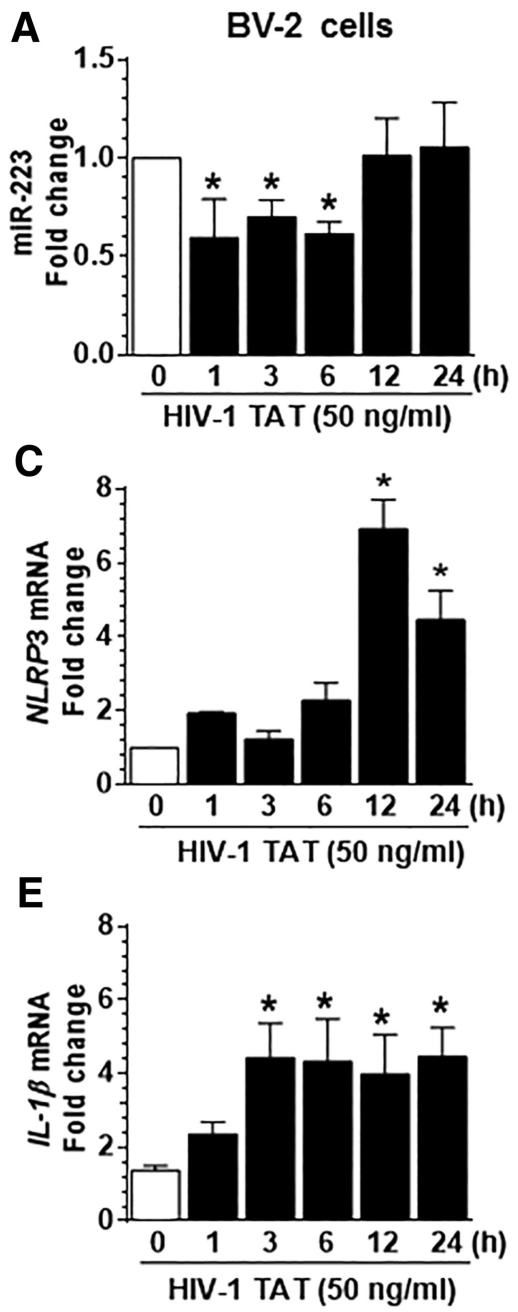

Figure 6. Tat modulates NLRP3 inflammasome activation by inhibiting expression of its negative regulator, miR-223. BV-2 cells or rPMs were seeded into six-well plates, exposed to Tat $(50 \mathrm{ng} / \mathrm{ml})$, and monitored for expression of miR-223, NLRP3, and IL-1 $\beta$ levels over a $24 \mathrm{~h}$ time course by qRT-PCR. miR-223 was significantly decreased $(\boldsymbol{A}, \boldsymbol{B})$ and, conversely, NLRP3 was increased $(\boldsymbol{C}, \boldsymbol{D})$ in both BV-2 and rPMs. IL-1 $\beta$ was similarly increased in both BV-2 and $\mathrm{rPMs}(\boldsymbol{E}, \boldsymbol{F})$. U6 served as a loading control. Data are expressed as mean \pm SEM.

Table 1. Viral load and CD4 cell counts of rhesus macaques

\begin{tabular}{|c|c|c|c|c|c|}
\hline \multirow[b]{2}{*}{$\begin{array}{l}\text { SIV } \\
\text { status }\end{array}$} & \multirow[b]{2}{*}{$\begin{array}{l}\text { Animal } \\
\text { ID }\end{array}$} & \multirow[b]{2}{*}{$\begin{array}{l}\text { Day of } \\
\text { euthanasia } \\
\text { (postinfection) }\end{array}$} & \multicolumn{3}{|c|}{ End point measurements } \\
\hline & & & $\begin{array}{l}\text { CD4 counts } \\
\text { (cells/ml) }\end{array}$ & $\begin{array}{l}\text { Plasma viral load } \\
\text { (copies/million } \\
\text { GAPDH) }\end{array}$ & $\begin{array}{l}\text { CSF viral load } \\
\text { (copies/million } \\
\text { GAPDH) }\end{array}$ \\
\hline SIV- & 40495 & N/A & 920 & $N / A$ & N/A \\
\hline SIV- & 40965 & $\mathrm{~N} / \mathrm{A}$ & 565 & $N / A$ & N/A \\
\hline SIV- & 41056 & $\mathrm{~N} / \mathrm{A}$ & 1273 & $N / A$ & N/A \\
\hline SIV+ & 39104 & $22 \mathrm{dSIV}$ & 933 & 2,218,344 & 69,133 \\
\hline SIV+ & 39154 & $22 \mathrm{dSIV}$ & 552 & 691,735 & 32,919 \\
\hline SIV+ & 39368 & $23 \mathrm{~d}$ SIV & 1012 & $10,518,444$ & $5,835,276$ \\
\hline SIV+ & C1 & 52 wk SIV & 249 & 202,120 & 6,574 \\
\hline SIV+ & C & 52 wk SIV & 132 & $5,380,728$ & 633,917 \\
\hline SIV+ & C4 & 52 wk SIV & 172 & 837,406 & 49,212 \\
\hline
\end{tabular}

with uninfected controls (Fig. 7A; $p<0.05$ ). Expression levels of the adaptor protein ASC were found to be significantly upregulated in the basal ganglia of SIV-infected macaques during acute infection, with a trend of upregulation during chronic SIV infection (Fig. $7 B ; p<0.05$ ). As shown in Figure 7, $C$ and $D$, plasma IL- $1 \beta$ and IL-18 levels also exhibited enhanced expression, suggesting that, similar to HIV-1 Tat, SIV infection also activated
NLRP3 inflammasomes in vivo. Interestingly, miR-223 showed a decreasing trend in the basal ganglia of SIV-infected macaques during acute infection, with a restoration during the chronic infection stage (Fig. 7E).

\section{Increased inflammation response to} LPS in the brains of HIV-1 Tg rats

Having demonstrated that exposure to Tat primes microglia, we next sought to explore whether a similar phenomenon existed in vivo. We rationalized that priming by HIV-1 proteins in the HIV Tg rat would subsequently enhance the capacity of the CNS to mount a stronger immune response to a secondary stimulus such as LPS. For this, 18-month-old (to ensure accumulation of viral proteins including Tat) HIV-1 Tg and wild-type rats of both the sexes were challenged with a low dose of LPS ( $1 \mathrm{mg} / \mathrm{kg}$, i.p.), followed by isolation of the striatum for expression of proinflammatory cytokines (IL- $1 \beta$ and IL-6) mRNAs by qRT-PCR. As shown in Figure $8 A$, in the absence of LPS, HIV-1 Tg rats exhibited increased expression of IL- $1 \beta$ (2.3-fold increase) compared with the wild-type controls, confirming that in vivo priming was likely induced due to the presence of HIV-1 proteins. Interestingly however, after LPS challenge, HIV-1 Tg rats exhibited a further upregulation of IL-1 $\beta$ mRNA (4.2-fold increase) compared with the wild-type rats (2.4-fold increase). Similarly, expression of IL-6, another early proinflammatory cytokine, was also increased up to 3 -fold in HIV-1 Tg rats compared with an $\sim 1$.8-fold increase in wild-type rats in the presence of LPS (Fig. 8B). To confirm the involvement of NLPR3 inflammasome in HIV and LPS-mediated activation, protein lysates containing ASC oligomers were isolated from the striatum of HIV Tg and WT rats that were administered LPS. As shown in Figure 8C, there was increased presence of ASC oligomers in the striatum of $\mathrm{HIV}-1 \mathrm{Tg}$ rats compared with the controls. Furthermore, caspase 1 was also found to be activated (Fig. $8 C$ ) and, as shown in Figure $8 D$, there was increased cleavage of IL- $1 \beta$ into its active $\mathrm{p} 17$ form in the striatum of three of four HIV-1 Tg/LPS rats compared with the WT/LPS group.

\section{Discussion}

HAND remains a major cause of morbidity in HIV-1-positive individuals despite the use of cART (Saylor et al., 2016). However, in CART-treated persons, the milder forms of the disease such as ANI or MND continue to increase in prevalence, accounting for $\sim 70 \%$ of HAND (Saylor et al., 2016), whereas HAD has declined drastically. As reviewed by Saylor et al. (2016), substantial evidence suggests a critical role for inflammation in HAND. HIV-1 Tat protein has been reported to be present in the brains of infected individuals and is implicated in the development of HAND (Del Valle et al., 2000; Hudson et al., 2000; Li et al., 2009; Johnson et al., 2013). In this study, we examined the 
mechanisms underlying Tat-mediated microglial activation with a focus on NLRP3 inflammasome pathway. Our data show that Tat can prime and activate the NLRP3 inflammasome in microglia, resulting in the release of IL- $1 \beta$, a highly potent cytokine that in turn induces other cytokines, including IL- 6 and TNF- $\alpha$, to further exacerbate inflammation. Our findings are consistent with previous reports demonstrating induction of the NLRP3 inflammasome in microglia and monocytes after HIV-1 infection (Guo et al., 2014; Hernandez et al., 2014; Walsh et al., 2014). They further suggest that Tatmediated priming of NLRP3 may contribute in part to sustained CNS inflammation despite suppression of viral replication by cART and likely in response to a second stimulus such as LPS. In addition to increased release of IL- $1 \beta$, microglia primed by Tat could become more sensitive to the effects of other proinflammatory factors previously described as NLRP3 activators such as lipotoxic fatty acids, ceramides, and free cholesterol (Duewell et al., 2010; Vandanmagsar et al., 2011; Wen et al., 2011). Interestingly, individuals who develop ANI and MND have elevated levels of NLRP3 activators such as ceramide and multiple forms of cholesterol compared with cognitively normal HIV-1-positive individuals (Bandaru et al., 2013).

To understand whether priming first with a stimulus such as HIV-1 protein would subsequently increase the CNS inflammatory response to a secondary stimulus such as LPS, we sought to use the HIV-1 Tg rat model. HIV-1 Tg rats develop neurological abnormalities analogous to those observed in HIV-1-infected humans, with an accumulation of HIV proteins, thereby mimicking aspects of NeuroAIDS (Reid et al., 2001; Peng et al., 2010; Royal et al., 2012; Vigorito et al., 2015). HIV-1 Tg rats administered with acute, low-dose LPS demonstrated height-

ened activation of NLRP3 inflammasome pathway mediators such as IL-1 $\beta$, ASC oligomers, and Caspase-1 compared with wild-type controls with LPS. In addition, there was also upregulation of IL-6 mRNA in HIV Tg rats exposed to LPS compared with WT controls exposed to LPS, thereby underscoring a wider priming of proinflammatory pathways.

Tat has been demonstrated to enter cells by several mechanisms such as clathrin-mediated endocytosis, binding with TLR4, or integrins (Barillari et al., 1999; Vendeville et al., 2004; Johnson et al., 2013). After uptake, Tat is found in both the cytoplasm and the nucleus (Johnson et al., 2013). In one study, Tat-mediated induction of IL-17 was completely inhibited after attenuation of clathrin-mediated endocytosis by amiloride or chlorpromazine (Johnson et al., 2013), suggesting a major role for receptormediated endocytosis in Tat entry and activation of immune cells. Similarly, Tat was shown to bind to TLR4 and MD-2, result-
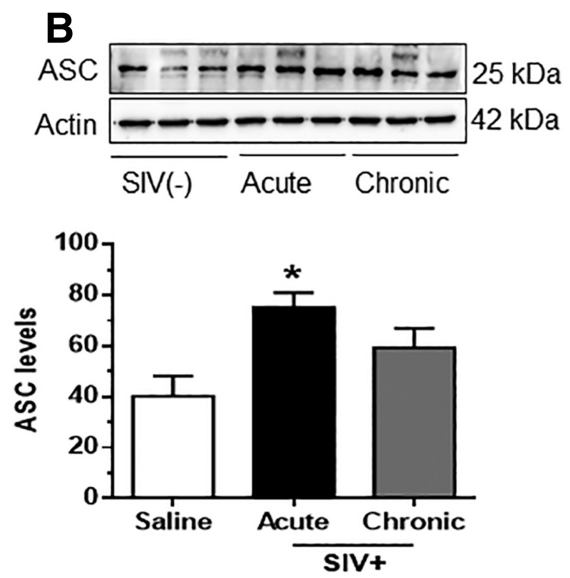

D

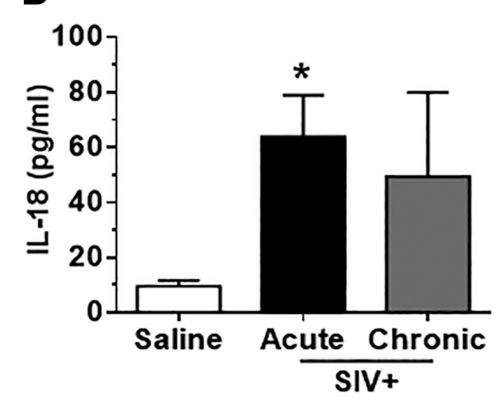

Figure 7. SIV infection of monkeys induced expression of NLRP3 pathway mediators in both the CNS and plasma. Rhesus monkeys (RMs) ( $n=3$ /group) were infected with SIV and monitored at 2 weeks (acute) or at necropsy (maximum 52 weeks) for

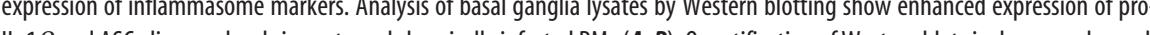
blot. Data are shown as mean \pm SEM. In plasma samples, IL-1 $\beta$ was induced 8 -fold and 5 -fold in acute and chronic SIV-positive RMs, respectively (C). IL-18 showed a similar pattern, with 6-fold and 5-fold increases at the acute and chronic stages, respectively (D). MiR-223 was reduced in the basal ganglia of SIV-infected RMs, with a restoration in chronically infected animals $(\boldsymbol{E})$.

ing in the induction of the cytokines TNF- $\alpha$ and IL-10 (Ben Haij et al., 2013). These studies suggest that endocytosed Tat may exert biological effects within cells by regulating the expression of proinflammatory mediators such as MCP-1, TNF- $\alpha$, and IL17 (Ensoli et al., 1993; Nath et al., 1999; Weiss et al., 1999; El-Hage et al., 2005; Ben Haij et al., 2013; Johnson et al., 2013) and including activation of NLRP3 as reported here.

Intriguingly, our data show for the first time that Tat can both prime and activate the NLRP3 inflammasome. Pathogen-associated molecular patterns such as LPS prime NLRP3 and IL- $1 \beta$ through activation of NF-kB transcription factor, which, in turn can bind to the NLRP3 promoter region (Qiao et al., 2012). This is important because basal levels of NLRP3 are inadequate for efficient inflammasome formation (Sutterwala et al., 2014). Posttranscriptionally, NLRP3 is tightly regulated by miR-223, which targets conserved miR-223-binding sites in its $3^{\prime}$-UTR (Bauernfeind et 
A

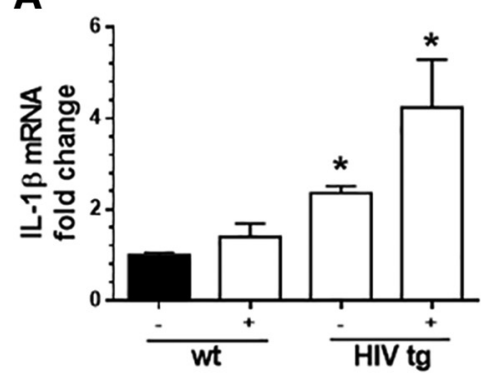

C
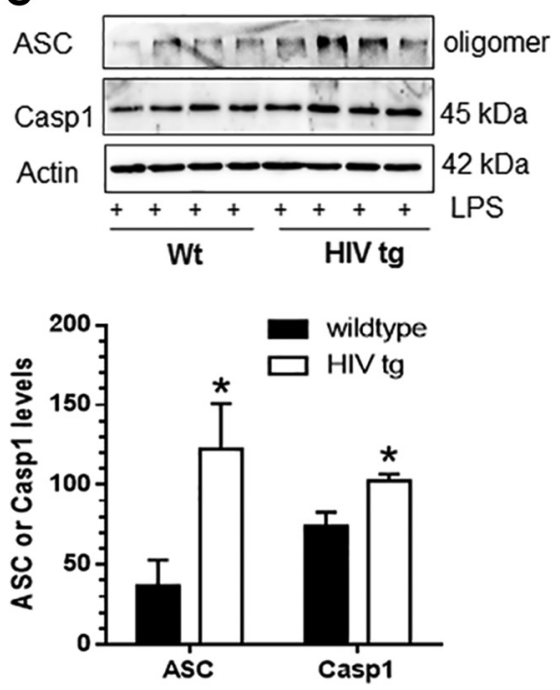

Figure 8. HIV-1 Tg rats show an enhanced response to LPS administration. Wild-type and HIV-1 Tg rats were challenged by administration of a low dose of LPS (1 mg/kg, i.p.) and assessed for NLRP3 activation and inflammatory cytokines in the striatum. Analyses of the striatum by qRT-PCR showed upregulation of both IL- $1 \beta$ and IL- 6 mRNA in HIV-1 Tg rats, with demonstration of a more robust response to LPS challenge compared with the wild-type controls $(\boldsymbol{A}, \boldsymbol{B})$. Increased presence of ASC oligomers was observed in the striatum of HIV-1 Tg rats compared with WT controls (C). Caspase 1 and IL-1 $\beta$ activation was also increased in the striatum of HIV- 1 Tg rats compared with WT controls $(C, D) . n=4$ /group.

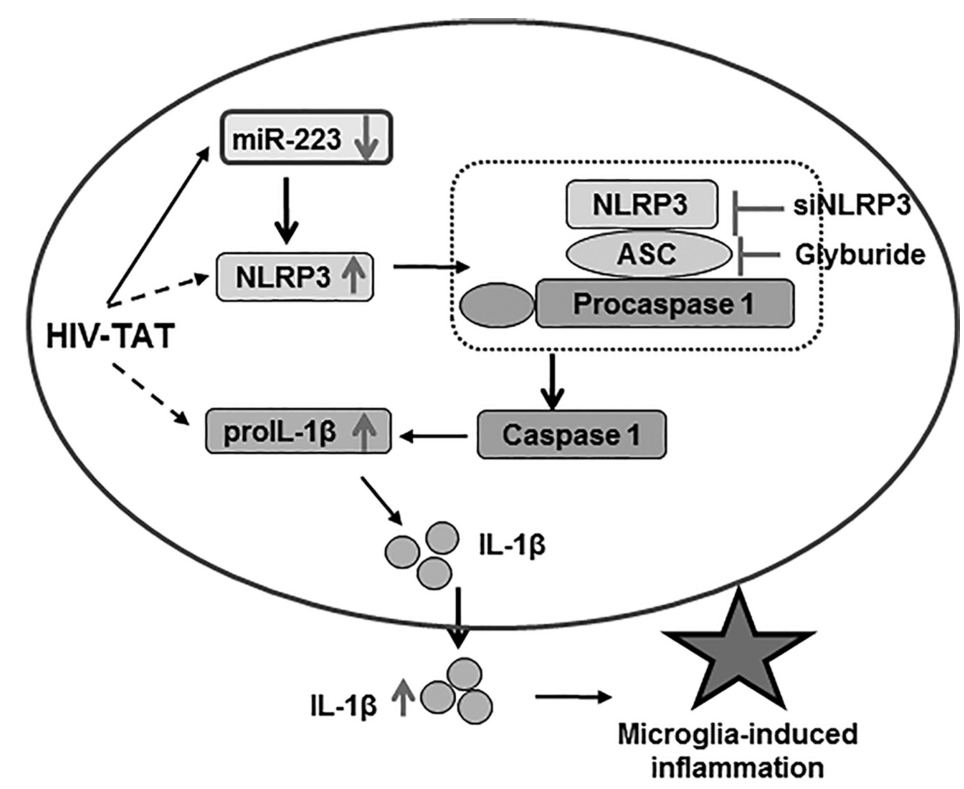

Figure 9. Schematic description of HIV-1 Tat-mediated priming and activation of NLRP3 inflammasomes in microglia. Tat enhances NLRP3 and IL-1 $\beta$ expression, thus priming the inflammasome. Efficient priming is enhanced in a mechanism involving inhibition of miR-223, a negative regulator of NLRP3. The inflammasome is subsequently activated resulting in the processing of Caspase 1 and the maturation and release of IL- $\beta$. al., 2012; Haneklaus et al., 2012; Haneklaus et al., 2013; Yang et al., 2015). Interestingly, activation of $\mathrm{CD} 4+\mathrm{T}$ cells has been shown to downregulate miR-223 expression (Chiang et al., 2012). Furthermore, miR-223 targets the $3^{\prime}$ end of HIV-1 viral transcripts (Huang et al., 2007), suggesting a role for miR-223 in HIV-1-induced immune cell activation. Herein, we demonstrated that exposure of microglia to Tat reduced the expression levels of miR-223, leading to upregulated expression of its target, NLRP3. miR-223 expression has also been shown to be dysregulated by viral infections such as $\mathrm{H} 1 \mathrm{~N} 1$ influenza and hepatitis $\mathrm{B}$, further supporting a role for miR-223 in infectioninduced inflammation (Li et al., 2010; Xu et al., 2011; Haneklaus et al., 2013).

After NLRP3 priming, endogenous agonists such as ATP and calcium trigger inflammasome activation. Our data show that Tat is unique in its ability to activate NLRP3 on its own. Because Tat can increase intracellular calcium levels (Benelli et al., 2000; Mayne et al., 2000) and calcium is an NLRP3 inflammasome activator (Lee et al., 2012; Rossol et al., 2012), it is likely that Tat-induced inflammasome activation is dependent on its ability to modulate ion fluxes, particularly its capacity to enhance intracellular calcium levels. Although a definitive mechanism for NLRP3 inflammasome activation remains elusive, activators are thought to trigger some common pathways such as cationic fluxes that ultimately activate the inflammasome (Sutterwala et al., 2014). Future studies using Tat-exposed cells could help to clarify the ionic requirements for NLRP3 inflammasome activation.

In this study, the requirement of NLRP3 for Tat-mediated IL-1 $\beta$ release was confirmed using both pharmacological inhibition (glyburide) and genetic (NLRP3 siRNA) approaches. Several small molecules have been shown to inhibit NLRP3, including glyburide, $\beta$-hydroxybutyrate, pathernolide, bay11-7082, and MCC950 (Lamkanfi et al., 2009; Juliana et al., 2010; Coll et al., 2015; Youm et al., 2015). In this study, we describe glyburide-mediated inhibition of caspase-1 processing and IL- $1 \beta$ release in microglia exposed to Tat. Correspondingly, we showed that siRNA knock-down of NLRP3 diminished Tatinduced NLRP3 priming and the downstream effectors caspase- 1 and IL- $1 \beta$. With the discovery and design of safer NLRP3 inhibitory molecules, trials in animal models of HAND will be useful to evaluate the efficacy of NLRP3 inhibition in ameliorating HIV-1-associated inflamma- 
tion. We propose that inhibition of NLRP3 with small-molecule inhibitors could serve as an adjunctive therapeutic strategy to treat or prevent the development of HAND.

In summary, our novel findings demonstrate that Tat-mediated release of IL- $1 \beta$ in microglial cells involves priming and activation of the NLRP3 inflammasome, as illustrated in Figure 9. Tatmediated release of IL- $1 \beta$ could contribute to neuroinflammation and exacerbate HIV-1-associated neurological disease. These findings suggest that inhibition of NLRP3 inflammasomes could provide a platform for the development of novel approaches to reduce neuroinflammation and subsequent neuronal impairment in HIV-1-positive patients with ramifications for other neurodegenerative disorders involving inflammasomes.

\section{References}

Ambros V (2004) The functions of animal microRNAs. Nature 431:350355. CrossRef Medline

Antinori A, et al. (2007) Updated research nosology for HIV-associated neurocognitive disorders. Neurology 69:1789-1799. CrossRef Medline

Bandaru VV, Mielke MM, Sacktor N, McArthur JC, Grant I, Letendre S, Chang L, Wojna V, Pardo C, Calabresi P, Munsaka S, Haughey NJ (2013) A lipid storage-like disorder contributes to cognitive decline in HIVinfected subjects. Neurology 81:1492-1499. CrossRef Medline

Barillari G, Sgadari C, Fiorelli V, Samaniego F, Colombini S, Manzari V, Modesti A, Nair BC, Cafaro A, Stürzl M, Ensoli B (1999) The Tat protein of human immunodeficiency virus type- 1 promotes vascular cell growth and locomotion by engaging the alpha5betal and alphavbeta 3 integrins and by mobilizing sequestered basic fibroblast growth factor. Blood 94: 663-672. Medline

Bauernfeind F, Rieger A, Schildberg FA, Knolle PA, Schmid-Burgk JL, Hornung V (2012) NLRP3 inflammasome activity is negatively controlled by miR-223. J Immunol 189:4175-4181. CrossRef Medline

Ben Haij N, Leghmari K, Planès R, Thieblemont N, Bahraoui E (2013) HIV-1 Tat protein binds to TLR4-MD2 and signals to induce TNF-alpha and IL-10. Retrovirology 10:123. CrossRef Medline

Benelli R, Barbero A, Ferrini S, Scapini P, Cassatella M, Bussolino F, Tacchetti C, Noonan DM, Albini A (2000) Human immunodeficiency virus transactivator protein (Tat) stimulates chemotaxis, calcium mobilization, and activation of human polymorphonuclear leukocytes: implications for Tat-mediated pathogenesis. J Infect Dis 182:1643-1651. CrossRef Medline

Bokhari SM, Hegde R, Callen S, Yao H, Adany I, Li Q, Li Z, Pinson D, Yeh HW, Cheney PD, Buch S (2011) Morphine potentiates neuropathogenesis of SIV infection in rhesus macaques. J Neuroimmune Pharmacol 6:626-639. CrossRef Medline

Chiang K, Sung TL, Rice AP (2012) Regulation of cyclin T1 and HIV-1 Replication by microRNAs in resting CD4+ T lymphocytes. J Virol 86: 3244-3252. CrossRef Medline

Coll RC et al. (2015) A small-molecule inhibitor of the NLRP3 inflammasome for the treatment of inflammatory diseases. Nat Med 21:248255. Medline

Dandekar DH, Ganesh KN, Mitra D (2004) HIV-1 Tat directly binds to NFkappaB enhancer sequence: role in viral and cellular gene expression. Nucleic Acids Res 32:1270-1278. CrossRef Medline

de Alba E (2009) Structure and interdomain dynamics of apoptosisassociated speck-like protein containing a CARD (ASC). J Biol Chem 284:32932-32941. CrossRef Medline

Del Valle L, Croul S, Morgello S, Amini S, Rappaport J, Khalili K (2000) Detection of HIV-1 Tat and JCV capsid protein, VP1, in AIDS brain with progressive multifocal leukoencephalopathy. J Neurovirol 6:221-228. CrossRef Medline

Demarchi F, d'Adda di Fagagna F, Falaschi A, Giacca M (1996) Activation of transcription factor NF-kappaB by the Tat protein of human immunodeficiency virus type 1. J Virol 70:4427-4437. Medline

Duewell P, Kono H, Rayner KJ, Sirois CM, Vladimer G, Bauernfeind FG, Abela GS, Franchi L, Nuñez G, Schnurr M, Espevik T, Lien E, Fitzgerald KA, Rock KL, Moore KJ, Wright SD, Hornung V, Latz E (2010) NLRP3 inflammasomes are required for atherogenesis and activated by cholesterol crystals. Nature 464:1357-1361. CrossRef Medline

El-Hage N, Gurwell JA, Singh IN, Knapp PE, Nath A, Hauser KF (2005) Synergistic increases in intracellular $\mathrm{Ca} 2+$, and the release of MCP-1,
RANTES, and IL- 6 by astrocytes treated with opiates and HIV-1 Tat. Glia 50:91-106. CrossRef Medline

Ensoli B, Buonaguro L, Barillari G, Fiorelli V, Gendelman R, Morgan RA, Wingfield P, Gallo RC (1993) Release, uptake, and effects of extracellular human immunodeficiency virus type 1 Tat protein on cell growth and viral transactivation. J Virol 67:277-287. Medline

Filipowicz W, Bhattacharyya SN, Sonenberg N (2008) Mechanisms of posttranscriptional regulation by microRNAs: are the answers in sight? Nat Rev Genet 9:102-114. CrossRef Medline

Fiume G, Vecchio E, De Laurentiis A, Trimboli F, Palmieri C, Pisano A, Falcone C, Pontoriero M, Rossi A, Scialdone A, Fasanella Masci F, Scala G, Quinto I (2012) Human immunodeficiency virus-1 Tat activates NFkappaB via physical interaction with IkappaB-alpha and p65. Nucleic Acids Res 40:3548-3562. CrossRef Medline

Gannon P, Khan MZ, Kolson DL (2011) Current understanding of HIVassociated neurocognitive disorders pathogenesis. Curr Opin Neurol 24: 275-283. CrossRef Medline

Gray F, Chrétien F, Vallat-Decouvelaere AV, Scaravilli F (2003) The changing pattern of HIV neuropathology in the HAART era. J Neuropathol Exp Neurol 62:429-440. CrossRef Medline

Gross O, Thomas CJ, Guarda G, Tschopp J (2011) The inflammasome: an integrated view. Immunol Rev 243:136-151. CrossRef Medline

Guo H, Gao J, Taxman DJ, Ting JP, Su L (2014) HIV-1 infection induces interleukin-1beta production via TLR8 protein-dependent and NLRP3 inflammasome mechanisms in human monocytes. J Biol Chem 289: 21716-21726. CrossRef Medline

Guo ML, Liao K, Periyasamy P, Yang L, Cai Y, Callen SE, Buch S (2015) Cocaine-mediated microglial activation involves the ER stress-autophagy axis. Autophagy 11:995-1009. CrossRef Medline

Haneklaus M, Gerlic M, Kurowska-Stolarska M, Rainey AA, Pich D, McInnes IB, Hammerschmidt W, O'Neill LA, Masters SL (2012) Cutting edge: miR-223 and EBV miR-BART15 regulate the NLRP3 inflammasome and IL-1beta production. J Immunol 189:3795-3799. CrossRef Medline

Haneklaus M, Gerlic M, O'Neill LA, Masters SL (2013) miR-223: infection, inflammation and cancer. J Intern Med 274:215-226. CrossRef Medline

Heaton RK, et al. (2011) HIV-associated neurocognitive disorders before and during the era of combination antiretroviral therapy: differences in rates, nature, and predictors. J Neurovirol 17:3-16. CrossRef Medline

Hernandez JC, Latz E, Urcuqui-Inchima S (2014) HIV-1 induces the first signal to activate the NLRP3 inflammasome in monocyte-derived macrophages. Intervirology 57:36-42. CrossRef Medline

$\mathrm{Hu}$ G, Yao H, Chaudhuri AD, Duan M, Yelamanchili SV, Wen H, Cheney PD, Fox HS, Buch S (2012) Exosome-mediated shuttling of microRNA-29 regulates HIV Tat and morphine-mediated neuronal dysfunction. Cell Death Dis 3:e381. CrossRef Medline

Huang J, Wang F, Argyris E, Chen K, Liang Z, Tian H, Huang W, Squires K, Verlinghieri G, Zhang H (2007) Cellular microRNAs contribute to HIV-1 latency in resting primary CD4 + T lymphocytes. Nat Med 13: 1241-1247. CrossRef Medline

Hudson L, Liu J, Nath A, Jones M, Raghavan R, Narayan O, Male D, Everall I (2000) Detection of the human immunodeficiency virus regulatory protein tat in CNS tissues. J Neurovirol 6:145-155. CrossRef Medline

Johnson TP, Patel K, Johnson KR, Maric D, Calabresi PA, Hasbun R, Nath A (2013) Induction of IL-17 and nonclassical T-cell activation by HIV-Tat protein. Proc Natl Acad Sci U S A 110:13588-13593. CrossRef Medline

Jovičić A, Roshan R, Moisoi N, Pradervand S, Moser R, Pillai B, Luthi-Carter R (2013) Comprehensive expression analyses of neural cell-type-specific miRNAs identify new determinants of the specification and maintenance of neuronal phenotypes. J Neurosci 33:5127-5137. CrossRef Medline

Juliana C, Fernandes-Alnemri T, Wu J, Datta P, Solorzano L, Yu JW, Meng R, Quong AA, Latz E, Scott CP, Alnemri ES (2010) Anti-inflammatory compounds parthenolide and Bay 11-7082 are direct inhibitors of the inflammasome. J Biol Chem 285:9792-9802. CrossRef Medline

Koka P, He K, Zack JA, Kitchen S, Peacock W, Fried I, Tran T, Yashar SS, Merrill JE (1995) Human immunodeficiency virus 1 envelope proteins induce interleukin 1, tumor necrosis factor alpha, and nitric oxide in glial cultures derived from fetal, neonatal, and adult human brain. J Exp Med 182:941-951. CrossRef Medline

Lamkanfi M, Mueller JL, Vitari AC, Misaghi S, Fedorova A, Deshayes K, Lee WP, Hoffman HM, Dixit VM (2009) Glyburide inhibits the Cryopyrin/ Nalp3 inflammasome. J Cell Biol 187:61-70. CrossRef Medline

Lee GS, Subramanian N, Kim AI, Aksentijevich I, Goldbach-Mansky R, Sacks 
DB, Germain RN, Kastner DL, Chae JJ (2012) The calcium-sensing receptor regulates the NLRP3 inflammasome through $\mathrm{Ca} 2+$ and cAMP. Nature 492:123-127. CrossRef Medline

Liao K, Guo M, Niu F, Yang L, Callen SE, Buch S (2016) Cocaine-mediated induction of microglial activation involves the ER stress-TLR2 axis. J Neuroinflammation 13:33. CrossRef Medline

Li W, Li G, Steiner J, Nath A (2009) Role of Tat protein in HIV neuropathogenesis. Neurotox Res 16:205-220. CrossRef Medline

Li Y, Chan EY, Li J, Ni C, Peng X, Rosenzweig E, Tumpey TM, Katze MG (2010) MicroRNA expression and virulence in pandemic influenza virus-infected mice. J Virol 84:3023-3032. CrossRef Medline

Maingat FG, Polyak MJ, Paul AM, Vivithanaporn P, Noorbakhsh F, Ahboucha S, Baker GB, Pearson K, Power C (2013) Neurosteroid-mediated regulation of brain innate immunity in HIV/AIDS: DHEA-S suppresses neurovirulence. FASEB J 27:725-737. CrossRef Medline

Maschke M, Kastrup O, Esser S, Ross B, Hengge U, Hufnagel A (2000) Incidence and prevalence of neurological disorders associated with HIV since the introduction of highly active antiretroviral therapy (HAART). J Neurol Neurosurg Psychiatry 69:376-380. CrossRef Medline

Mayne M, Holden CP, Nath A, Geiger JD (2000) Release of calcium from inositol 1,4,5-trisphosphate receptor-regulated stores by HIV-1 Tat regulates TNF-alpha production in human macrophages. J Immunol 164: 6538-6542. CrossRef Medline

McArthur JC, Haughey N, Gartner S, Conant K, Pardo C, Nath A, Sacktor N (2003) Human immunodeficiency virus-associated dementia: an evolving disease. J Neurovirol 9:205-221. CrossRef Medline

Merrill JE, Koyanagi Y, Zack J, Thomas L, Martin F, Chen IS (1992) Induction of interleukin-1 and tumor necrosis factor alpha in brain cultures by human immunodeficiency virus type 1. J Virol 66:2217-2225. Medline

Moon JS, Lee S, Park MA, Siempos II, Haslip M, Lee PJ, Yun M, Kim CK, Howrylak J, Ryter SW, Nakahira K, Choi AM (2015) UCP2-induced fatty acid synthase promotes NLRP3 inflammasome activation during sepsis. J Clin Invest 125:665-680. CrossRef Medline

Nath A, Conant K, Chen P, Scott C, Major EO (1999) Transient exposure to HIV-1 Tat protein results in cytokine production in macrophages and astrocytes. A hit and run phenomenon. J Biol Chem 274:17098-17102. CrossRef Medline

Nightingale S, Winston A, Letendre S, Michael BD, McArthur JC, Khoo S, Solomon T (2014) Controversies in HIV-associated neurocognitive disorders. Lancet Neurol 13:1139-1151. CrossRef Medline

Peng J, Vigorito M, Liu X, Zhou D, Wu X, Chang SL (2010) The HIV-1 transgenic rat as a model for HIV-1 infected individuals on HAART. J Neuroimmunol 218:94-101. CrossRef Medline

Qiao Y, Wang P, Qi J, Zhang L, Gao C (2012) TLR-induced NF-kappaB activation regulates NLRP3 expression in murine macrophages. FEBS Lett 586:1022-1026. CrossRef Medline

Rathinam VA, Vanaja SK, Fitzgerald KA (2012) Regulation of inflammasome signaling. Nat Immunol 13:333-342. CrossRef Medline

Reid W, et al. (2001) An HIV-1 transgenic rat that develops HIV-related pathology and immunologic dysfunction. Proc Natl Acad Sci U S A 98: 9271-9276. CrossRef Medline

Rossol M, Pierer M, Raulien N, Quandt D, Meusch U, Rothe K, Schubert K, Schöneberg T, Schaefer M, Krügel U, Smajilovic S, Bräuner-Osborne H, Baerwald C, Wagner U (2012) Extracellular Ca2+ is a danger signal activating the NLRP3 inflammasome through $G$ protein-coupled calcium sensing receptors. Nat Commun 3:1329. CrossRef Medline

Royal W 3rd, Zhang L, Guo M, Jones O, Davis H, Bryant JL (2012) Immune activation, viral gene product expression and neurotoxicity in the HIV-1 transgenic rat. J Neuroimmunol 247:16-24. CrossRef Medline

Sacktor N, McDermott MP, Marder K, Schifitto G, Selnes OA, McArthur JC, Stern Y, Albert S, Palumbo D, Kieburtz K, De Marcaida JA, Cohen B,
Epstein L (2002) HIV-associated cognitive impairment before and after the advent of combination therapy. J Neurovirol 8:136-142. CrossRef Medline

Saylor D, Dickens AM, Sacktor N, Haughey N, Slusher B, Pletnikov M, MankowskiJL, Brown A, Volsky DJ, McArthurJC (2016) HIV-associated neurocognitive disorder-pathogenesis and prospects for treatment. Nat Rev Neurol 12:234-248. CrossRef Medline

Sutterwala FS, Haasken S, Cassel SL (2014) Mechanism of NLRP3 inflammasome activation. Ann N Y Acad Sci 1319:82-95. CrossRef Medline

Vandanmagsar B, Youm YH, Ravussin A, Galgani JE, Stadler K, Mynatt RL, Ravussin E, Stephens JM, Dixit VD (2011) The NLRP3 inflammasome instigates obesity-induced inflammation and insulin resistance. Nat Med 17:179-188. CrossRef Medline

Vendeville A, Rayne F, Bonhoure A, Bettache N, Montcourrier P, Beaumelle B (2004) HIV-1 Tat enters T cells using coated pits before translocating from acidified endosomes and eliciting biological responses. Mol Biol Cell 15:2347-2360. CrossRef Medline

Vigorito M, Connaghan KP, Chang SL (2015) The HIV-1 transgenic rat model of neuroHIV. Brain Behav Immun 48:336-349. CrossRef Medline

Walsh JG, Reinke SN, Mamik MK, McKenzie BA, Maingat F, Branton WG, Broadhurst DI, Power C (2014) Rapid inflammasome activation in microglia contributes to brain disease in HIV/AIDS. Retrovirology 11:35. CrossRef Medline

Wang X, Spandidos A, Wang H, Seed B (2012) PrimerBank: a PCR primer database for quantitative gene expression analysis, 2012 update. Nucleic Acids Res 40:D1144-1149. CrossRef Medline

Weiss JM, Nath A, Major EO, Berman JW (1999) HIV-1 Tat induces monocyte chemoattractant protein-1-mediated monocyte transmigration across a model of the human blood-brain barrier and upregulates CCR5 expression on human monocytes. J Immunol 163:29532959. Medline

Wen H, Gris D, Lei Y, Jha S, Zhang L, Huang MT, Brickey WJ, Ting JP (2011) Fatty acid-induced NLRP3-ASC inflammasome activation interferes with insulin signaling. Nat Immunol 12:408-415. CrossRef Medline

Xing HQ, Moritoyo T, Mori K, Sugimoto C, Ono F, Izumo S (2009) Expression of proinflammatory cytokines and its relationship with virus infection in the brain of macaques inoculated with macrophage-tropic simian immunodeficiency virus. Neuropathology 29:13-19. CrossRef Medline

Xu J, Wu C, Che X, Wang L, Yu D, Zhang T, Huang L, Li H, Tan W, Wang C, Lin D (2011) Circulating microRNAs, miR-21, miR-122, and miR-223, in patients with hepatocellular carcinoma or chronic hepatitis. Mol Carcinog 50:136-142. CrossRef Medline

Yang Y, Wu J, Lu Y (2010) Mechanism of HIV-1-TAT induction of interleukin-1beta from human monocytes: Involvement of the phospholipase C/protein kinase C signaling cascade. J Med Virol 82:735-746. CrossRef Medline

Yang Z, Zhong L, Xian R, Yuan B (2015) MicroRNA-223 regulates inflammation and brain injury via feedback to NLRP3 inflammasome after intracerebral hemorrhage. Mol Immunol 65:267-276. CrossRef Medline

Youm YH, Nguyen KY, Grant RW, Goldberg EL, Bodogai M, Kim D, D’Agostino D, Planavsky N, Lupfer C, Kanneganti TD, Kang S, Horvath TL, Fahmy TM, Crawford PA, Biragyn A, Alnemri E, Dixit VD (2015) The ketone metabolite beta-hydroxybutyrate blocks NLRP3 inflammasome-mediated inflammatory disease. Nat Med 21:263-269. CrossRef Medline

Zayyad Z, Spudich S (2015) Neuropathogenesis of HIV: from initial neuroinvasion to HIV-associated neurocognitive disorder (HAND). Curr HIV/ AIDS Rep 12:16-24. CrossRef Medline

Zhao ML, Kim MO, Morgello S, Lee SC (2001) Expression of inducible nitric oxide synthase, interleukin-1 and caspase-1 in HIV-1 encephalitis. J Neuroimmunol 115:182-191. CrossRef Medline 